\title{
Stability of Two Probiotics Bacteria of Goat Milk Yoghurt in Rat Digestive Tract
}

\author{
RARAH RATIH ADJIE MAHESWARI ${ }^{*}$, \\ I KOMANG GEDE WIRYAWAN ${ }^{2}$ AND GINA LESMANA MADUNINGSIH ${ }^{1}$
}

${ }^{1}$ Department of Animal Production and Technology; ${ }^{2}$ Department of Animal Nutrition and Feed Technology, Institut Pertanian Bogor, Darmaga Campus, Bogor16680, Indonesia

\begin{abstract}
Increased age will affect the bacterial population of the human digestive tract, in which many bacteria will adapt and colonize different sites. Combining probiotics and prebiotics in what has been called a synbiotic could beneficially affect the host by improving survival and implantation/adhesion of live microbial dietary supplements in the gastrointestinal flora. Probiotic bacteria are expected to survive in the digestive tract to give health effects to the host by balancing the intestinal microflora. The addition of fructo-oligosaccharides is expected to increase viability and growth of probiotics in the digestive tract. The objective of the current research is to investigate the effect of probiotic yoghurt and synbiotic yoghurt of Etawa Breed Cross Saanen (PESA) goats together with fructo-oligosaccharides, on female rats and to study the stability of probiotic bacteria in the digestive tracts. The results showed that synbiotic yoghurt intake had no significant influence $(p>0.05)$ on ration consumption, body weight gain, feed conversion, final body weight and mortality. The synbiotic intake significantly increased the population of Bifidobacterium longum $(\mathrm{p}<0.01)$ and Lactobacillus acidophilus $(\mathrm{p}<0.05)$, but in contrast decreased $(\mathrm{p}<0.05)$ the population of Escherichia coli. The yoghurt synbiotic treatment over 14 days influenced probiotic bacteria's stability as shown by the reduced population of B. longum and L. acidophilus.
\end{abstract}

Key words: probiotic, prebiotic, yoghurt, digestive tract, synbiotic

Increased age will affect the bacterial population of the human digestive tract, in which many bacteria will adapt and colonize different sites. A probiotic is defined classically as a viable microbial dietary supplement that beneficially affects the host through its effects in the intestinal tract. This definition, however, was initially intended for use with animal feed. For human nutrition, the following definition has been proposed: "a live microbial food ingredient that is beneficial to health" (Salminen et al. 1998). Probiotic microorganisms that have a favorable influence on physiological and pathological processes of the host by their effect on the intestinal flora may play a role in improving human health (Erickson and Neil 2000). Some evidence suggests a role for probiotics in reducing the risk of rotavirus-induced diarrhea and colon cancer. Combining probiotics and prebiotics in what has been called a synbiotic could beneficially affect the host by improving survival and implantation of live microbial dietary supplements in the gastrointestinal flora. This takes place by selectively stimulating the growth, or activating, the catabolism of one, or a limited number of health-promoting bacteria in the intestinal tract, and by improving the gastrointestinal tract's microbial balance (Gibson and Roberfroid 1995). Human in vivo trials have established that the addition of fructo-oligosaccharides (FOS) or inulin to the diet leads to an increase in Bifidobacteria (Gibson et al. 1995; Bouhnik et al. 1996; Bouhnik et al. 1999; Kolida et al. 2002). Several studies have described fermentation in vitro of FOS in pure cultures of Bifidobacterium (McKellar and Modler 1989; Yamazaki and Dilawri 1990; Wang and Gibson 1993; Gibson and Wang 1994; Hopkins et al. 1998; Kaplan and Hutkins 2000; Perrin et al. 2001; Palframan et al. 2003). The combination of probiotics and prebiotics in a synbiotic might improve the survival of

\footnotetext{
${ }^{*}$ Corresponding author, Phone/Fax: +62-21-86283789,

E-mail: rarah_maheswari@yahoo.co.id
}

the bacteria crossing the upper part of the gastrointestinal tract, thereby enhancing their effects in the large bowel. In addition, their effects might be either additive or synergistic. The bifidobacteria and lactobacilli have been extensively studied and considered as valuable native inhabitants of the colon. However, the formulation of a synbiotic using probiotics from local collections or made from goat milk have not yet been investigated.

The criteria established to select suitable Bifidobacterium and Lactobacillus strains and to identify which strains posessing the desired traits are also the subject of many studies. Several specific characteristics possessed by these bacteria are thought to be either desirable or necessary. Probiotic bacteria should resist low $\mathrm{pH}$ and survive gastric acidity, bile salts at concentrations present in the intestinal tract, be able to adhere to intestinal mucosal cells and provide clinically proven benefits. Recently, it has been suggested that the ability of probiotic bacteria to ferment oligosaccharides may be an especially important characteristic (Gibson and Roberfroid 1995; Collins and Gibson 1999). This is because of the availability of carbohydrates that escape metabolism and adsorption in the small intestine and then have a major influence on the microbiota that become established in the colon.

Razafindrakoto et al. (1994) showed that goat's milk has equivalent nutritional value to cow's milk. Goat's milk can be used for undernourished children as an alternative to cow's milk. It may used at home for the prevention of malnutrition. Treatment with goat's milk in these experiments may be used to increase body weight of rats caused by easy absorption. Also it can increase therapheutic effect of synbiotic products.

The objective of this research is to investigate the effect of probiotic and synbiotic yoghurt of Etawa Breed Cross Saanen (PESA) goats as well as FOS, on female rats and to study the stability of probiotic bacteria in the digestive tracts. 
Female rats were used in this study, mainly because of their capability to have a high stress character, so the effect of probiotic and prebiotic expected to be determined easily.

\section{MATERIALS AND METHODS}

Bacteria Strains. The organisms used in this study include 4 strains, L. acidophilus RRM-01 (LA-RRM01) and B. longum RRM-01 (BL-RRM01) as probiotic bacteria, $L$. bulgaricus RRM-01 (LB-RRM01) and Streptococcus thermophillus RRM-01 (ST-RRM01) as yoghurt culture starters. The organisms were obtained from the Division of Dairy Production collection at Faculty of Animal Science, Bogor Agricultural University.

Preparation of Milk Base. Fresh raw PESA goats milk was purchased from the PT Fajar Taurus Dairy Farm, and skimmed to $0.4-1 \%(\mathrm{v} / \mathrm{v})$ fat using a cream separator. Milk was divided into 3 batches and heated $115^{\circ} \mathrm{C}$ for $3 \mathrm{~min}$.

Preparation of Probiotic Yoghurt and Synbiotic Yoghurt. The sterilized milk bases were cooled to incubation temperature, and batches of each milk base were inoculated

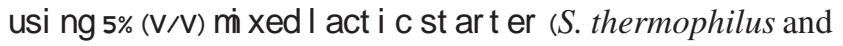
L. bulgaricus, 1:1) (yoghurt), 5\% (v/v) L. acidophilus starter (acidophilus milk) and 5\% (v/v) B. longum starter (bifidus milk) and incubated at $37^{\circ} \mathrm{C}$ for $20 \mathrm{~h}$. Probiotic yoghurt was made by mixing yoghurt, acidophillus milk and bifidus milk (2:1:1) and synbiotic yoghurt was made from probiotic yoghurt fortified with $0.9 \%$ (w/v) fructo-oligosaccharides (Cosucra, Belgium). Probiotic and synbiotic yoghurts were aseptically packed and stored at $4 \pm 1{ }^{\circ} \mathrm{C}$.

Animals. Fifteen weaned female sprague Dawley rats (Rattus novergicus), 21 days old, with an average body weight range of 30.40-30.92 $\mathrm{g}$ were used. The rats were kept in the Laboratory of Breeding and Genetics, Department of Animal Production and Technology, Faculty of Animal Science IPB. The rats were fed with pelleted starter broiler 511.

Experimental Design. Nine rats were randomly divided into 3 treatment groups with 3 replications of each. The treatments consisted of feeding with probiotic yoghurt of goat milk, R1; synbiotic yoghurt of goat milk, R2; and water (control), R3. The treatments were given orally at $0.03 \%$ $(\mathrm{v} / \mathrm{w})$ of rat body weight with initial bacterial population of $9.25 \log$ cfu ml-1 for L. acidophilus and $9.66 \log \mathrm{cfu} \mathrm{ml}^{-1}$ for $B$. longum. Observations were conducted over 42 days. Observations were also conducted on 6 rats (excluding R1, $\mathrm{R} 2, \mathrm{R} 3$ ) which are divided into two treatments, i.e. 3 rats adapted with broiler 511 pellets feed for 7 days to obtain an initial population of microorganisms, with the other treatment with synbiotic yoghurt of goat's milk for 42 days, after which treatment was stopped (withdrawal) for 14 days. The withdrawal-test of synbiotic yoghurt treatment was aimed at investigating its influence on probiotic bacterial population in the colon, consumption, body weight gain and feed conversion.

Adaptation. All rats were given pelleted starter broiler diet for 7 days and then each groups of rats for appropriate treatment were given appropriate diets (water, prebiotic yoghurt or symbiotic yoghurt) for 7 days prior to the main experiment.
Sampling. Faeces were obtained by placing the rats into sterile cages without rice hull bedding in the morning to allow the rats to defecate naturally. Analysis of faeces sample was conducted 2 weeks before each experiment was started and then 2, 4 and 6 weeks during each treatment for the first 3 groups of rats, and 2, 4, 6 and 8 weeks for rats with other treatments.

Rats colon were removed surgically after weighing in the $6^{\text {th }}$ weeks of treatment for the 3 groups of treated rats (main treatment) and in the $8^{\text {th }}$ week after treatment for the two other groups of rat with other treatments by placing the rats in a glass box containing cotton with $90 \%$ (w/v) chloroform for 3 minutes.

Preparation of Samples. One gram of fresh faeces was suspended in $9 \mathrm{ml}$ phosphate buffer and bacterial population (L. acidophilus, B. longum and E. coli) were estimated.

Statistical Analysis. Data were analyzed in a completely randomized design with 3 treatments and 3 replications of each treatment. Further analysis for significantly difference was conducted using Tukey test.

Parameters Observed. The parameters observed were: (i) consumption of feed dry matter ( $\mathrm{g} / \mathrm{head} / \mathrm{day}$ ), calculated by substracting dry matter of the ration offered with dry matter of the remaining ration; (ii) body weight gain (g/head/ day), obtained by substracting the final body weight from the initial body weight and dividing by the number days of the experiment; (iii) the value of feed conversion, expressed by the ratio between daily dry matter consumption and daily body weight gain; (iv) final body weight (g/head), obtained by weighing the rats at the end of the experiment; (v) mortality rate, expressed by the number of rats that died during the experiment. L. acidophilus enumerated using MRS-IM agar medium with maltose addition, whereas B. longum was enumerated using MRS-IM agar medium with addition of $20 \%$ glucose, $10 \%$ dichloxallin solution, $10 \% \mathrm{LiCl}$ and cystein $\mathrm{HCl}$. One gram of each sampel was serially diluted 10 times in sterile buffer peptone water. Enumeration was carried out using the pour plate technique. Suspended samples that had been diluted in phosphate buffer were cultured on Eosin Methylene Blue Agar (EMBA) and incubated at $35-37^{\circ} \mathrm{C}$ for $24 \mathrm{~h}$. Colonies that gave metallic green color were identified as E. coli.

\section{RESULTS}

Dry Matter Consumption, Body Weight Gain, Final Body Weight, Feed Conversion and Rat Mortality. The effects of the fermented milk on dry-matter consumption, body weight gain, final body weight and feed conversion are presented in Table 1 and 2. The mean dry matter consumption of the yoghurt treatment group was lower than in the control and the mean body weight gain and final body weight of the yoghurt treatment group was slightly higher than those of the control, but neither difference was significant $(\mathrm{p}<0.05)$. Although statistically the effect of treatment was not significant on feed conversion $(\mathrm{p}<0.05)$, we consider feed conversion of the yoghurt treatment to be a better than control because the mean of the feed conversion for the yoghurt treatment was lower than for its control. No rat mortality was observed during the experiment. This is 
Table 1 The effect of probiotic yoghurt and synbiotic yoghurt treatments on consumption, body weight gain, feed conversion, and final body weight of rats

\begin{tabular}{|c|c|c|c|}
\hline \multirow{2}{*}{ Parameters } & \multirow{2}{*}{ Control } & \multicolumn{2}{|c|}{ Treatments } \\
\hline & & Probiotic yoghurt & Synbiotic yoghurt \\
\hline Dry matter consumption (g/head/day) & $11.14 \pm 0.48$ & $10.64 \pm 0.91$ & $9.26 \pm 0.77$ \\
\hline Body weight gain (g/head/day) & $1.95 \pm 0.73$ & $2.68 \pm 0.12$ & $2.74 \pm 0.67$ \\
\hline Feed conversion & $6.27 \pm 2.24$ & $3.98 \pm 0.49$ & $3.47 \pm 0.57$ \\
\hline Final body weight $(\mathrm{g})$ & $144.60 \pm 28.39$ & $178.00 \pm 10.44$ & $181.90 \pm 35.60$ \\
\hline
\end{tabular}

Table 2 Response of synbiotic yoghurt treatment and without synbiotic yoghurt treatment

\begin{tabular}{lcr}
\hline \multicolumn{1}{c}{ Parameters } & Adaptation period & Without treatment for 14 days (post treatment) \\
\hline Dry matter consumption (g/head/day) & $12.67 \pm 1.05$ & $12.00 \pm 1.09$ \\
Body weight gain (g/head/day) & $2.98 \pm 0.15$ & $2.91 \pm 0.67$ \\
Feed conversion & $4.25 \pm 0.36$ & $4.33 \pm 1.34$ \\
\hline
\end{tabular}

because of the good environmental conditions that are suitable for the animals.

Population of Fecal Flora. The population of the bacterial flora in the faeces obtained during the control and the yoghurt treatment is shown in Fig 1-3. The presence of $B$. longum and $L$. acidophilus in the faeces during these experiments was variable.

The population of E. coli in the control treatment increased during the first 28 days. However, a significant decrease occurred at day 42. In contrast, constant population of $E$. coli was obtained in faeces of prebiotic-treated rats, while in the synbiotic yoghurt-treated rats the population of E. coli tended to decrease over 42 days. The population of E. coli in synbiotic-treated rats decreased by $1.12 \log \mathrm{cfu} \mathrm{g}^{-1}$. The growth curve of E. coli is shown in Fig 3.

Population of Colon Flora. The population of B. longum in the colon varied between 8.64-12.20 $\log \mathrm{cfu} \mathrm{g}^{-1}$. Differences in the increase of $B$. longum population in the colon was found in all of the treated-samples and in the control. However an analysis of variance shows that PESA goat milkbased synbiotic yoghurt feeding significantly influenced the population of $B$. longum in the colon $(\mathrm{p}<0.01)$. Variance analysis showed, an increase in the population of $L$. acidophilus was significant for the synbiotic-yoghurt intake $(\mathrm{p}<0.05)$.

The population of E. coli in the colon in all of the treatments varied between 5.40-8.34 $\log \mathrm{cfu} \mathrm{g}^{-1}$. Variance analysis showed that the synbiotic yoghurt-treated significantly decreased the population of $E$. coli $(\mathrm{p}<0.05)$.

\section{DISCUSSION}

Effect of Probiotic and Synbiotic Yoghurt Treatments. Feed consumption of rats fed with probiotic yoghurt and synbiotic yoghurt was lower than in their control. Previous studies have shown that, the food consumption of the goat's milk-based diet was lower than that for a normal diet (Aliaga et al. 2003). The type of diet given influences food intake, the goat's milk diet is consumed in smaller volumes. This might be caused by the special organoleptic characteristics of goat's milk, which have an intense aroma and a strong flavor and a slightly salty taste (Jandal 1996). Despite the lower food intake in rats given the goat's milk yoghurt diet, the body weight gain and final weight gain of rats treated

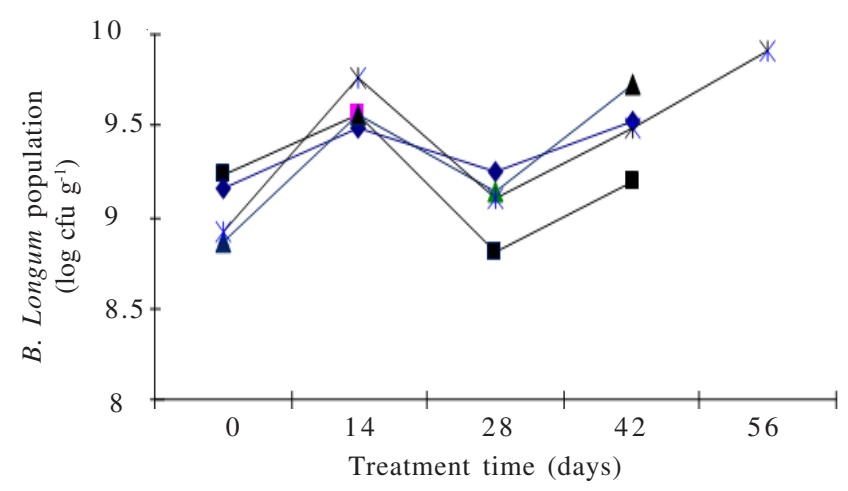

Fig 1 The effect of probiotic yoghurt ( ), synbiotic yoghurt $(\boldsymbol{\Delta})$, control/water ( $)$ and without treatment after 14 days ( $K^{\prime}$ ) on Bifidobacterium longum population in faeces.

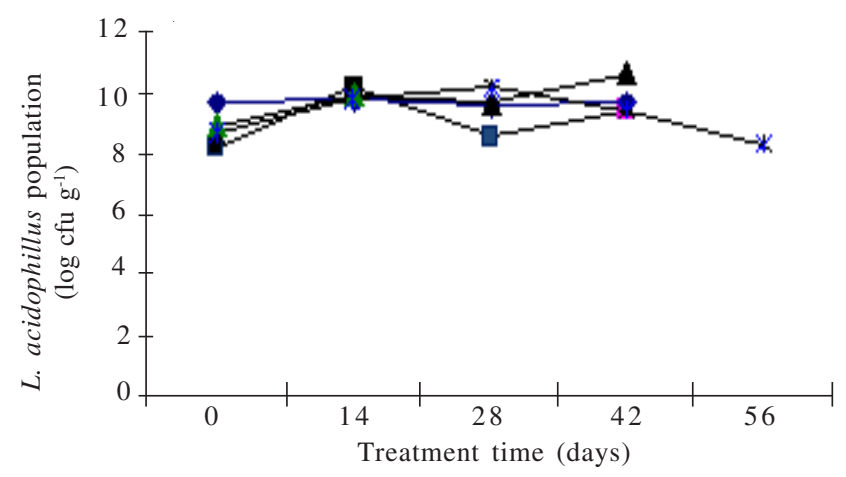

Fig 2 The effect of probiotic yoghurt $($ ), synbiotic yoghurt $(\boldsymbol{\Lambda})$ and control/water ( $)$, and without treatment after 14 days ( $*$ ) on Lactobacillus acidophillus population in faeces.

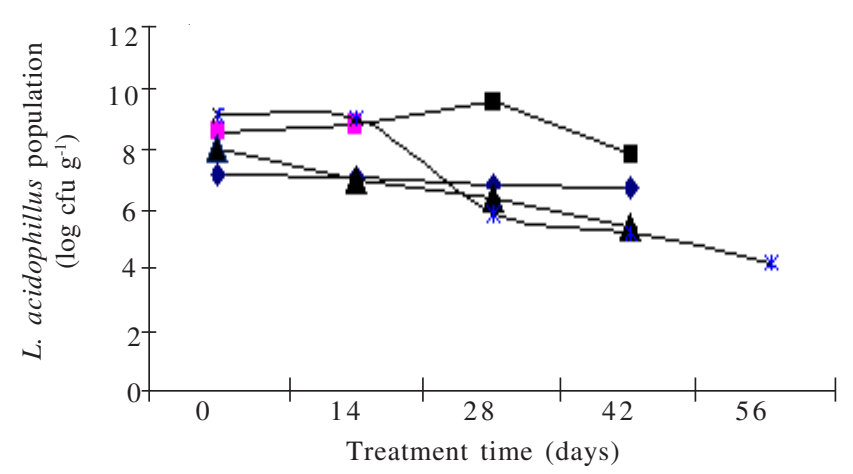

Fig 3 Effect of probiotic yoghurt ( ), synbiotic yoghurt ( $\boldsymbol{\Delta}$ ) and control/water (ם), without treatment after for 14 days ( ${ }^{\prime}$ ) on Escerichia coli population in faeces. 
with goat's milk yoghurt was slightly higher than those for the control. This fact is explained as the goat's milk yoghurt diet have a greater food conversion efficiency due to the nutrient content of goat's milk. Aliaga et al. (2003) showed use of the goat's milk diet led to a better food conversion efficiency with no significant differences in weight gain. The probiotic bacterias content in probiotic yoghurt and synbiotic yoghurt may influence feed consumption, body weight gain, feed conversion and final body weight. It is reported that $L$. acidophilus is able to increase digestibility and the utilization of protein (Jin et al. 1997). The same results were obtained by McDonough et al. (2006). They reported that rats treated with yoghurt had a higher body weight gain compared to rats given a non-fermented milk diet and that feed efficiencies for yoghurt diets were significantly higher than were efficiencies for milk diets. The composition of synbiotic yoghurt enriched with $L$. acidophilus and $B$. longum, as well as FOS, strongly supported the rat growth. The FOS prebiotic is used as a nutrient by L. acidophilus and $B$. longum for their optimum growth in the digestive tract, whereas L. acidophilus and B. longum produce metabolites beneficial to the host. These metabolite products can be used to form or increase the size of new cells which will influence body weight gain. Mortality refers to the number of dead rats caused by a treatment. Zero mortality is plausible since the enviromental coniditions satisfy all rat requirements.

Population of Fecal Flora. Besides their desired health and clinical properties, probiotics must meet several basic requirements for the development of marketable products. The most important requirements are that probiotic bacteria survive in sufficient numbers in the product, that their physical and genetic stability during storage of the product are guaranteed, and that all of their properties essential for expressing their health benefits after consumption are maintained during manufacture and storage of the product (Heller 2001). To ensure a probiotic health effect, bacterial cells must survive in intestinal passage and establish themselves in the terminal ileum or in the large intestine in sufficient numbers. This research shows high survival rates for B. longum and L. acidophilus in faeces. The growth curve of $B$. longum in faeces samples during our experiments behaves as a fluctuative curve (Fig 1). The same result was reported by Droault et al. (1999), stating that the presence of various antimicrobial peptides secreted by digestive tract of rats might play an important role to the bacterial viability inside of digestive tract itself. Antimicrobial peptides disturb permeability of the cell membrane leading to change transmembrane transport by create such hole inside. This reason gave for explaining the differences of microbial content in the faeces of rats. Although there were no significant differences in fecal bacterial counts, the bifidobacteria and L. acidophilus counts increased after ingestion of either the probiotic or the synbiotic yoghurt. Even though feeding of yoghurt was terminated after 14 days, population of $B$. longum in the rat's faeces still increased. Fuller (1989) stated that B. longum tend to adhere better to the digestive tract and forms which compete with pathogenic bacteria to obtain nutricional sources and colonization. Other studies showed that, L. bulgaricus and S. thermophilus might acted as bifidogenic factors on the resident colonic flora (Bartram et al. 1994). It has also been shown that Bifidobacteria survived the passage through the uppergastrointestinal tract after oral feeding (Poschart et al. 1992). The consumption of a prebiotic regulary promotes the composition of colon microbes, therefore Bifidobacteria is more likely to be viable in the colon and prominent in the faeces (Gibson and Roberfroid 1995). This result indicates that yoghurt consumption (in both probiotic and synbiotic forms) affects the colonic environment in a way that favors colonization with B. longum and L. acidophilus.

The addition of FOS may have supported the growth of B. longum and L. acidophilus. FOS are not degraded in the upper gastrointestinal tract by the enzymatic digestive system, but are easily metabolized by $B$. longum and $L$. acidophilus as carbon sources. The fermentation of FOS by bifidobacteria leads to the production of various organic acids. Formic acid was detected at low concentration in glucose and fructose fermentations. The main products of fermentations are three carbon sources as such lactic and acetic acids (Shene et al. 2005).

In its competition with pathogenic bacteria, B. longum was reported to have the ability to prevent membrane disruption by pathogenic bacteria. This ability may be delivered optimally in certain times and under appropriate condition (Davidson et al. 2000).

The population of B. longum reached $9.91 \log \mathrm{cfu} \mathrm{g}^{-1}$, which can be considered in the range of a probiotic population capable of promoting human health. Because the minimum suggested level of viable Bifidobacterium cells at the time of consumption is approximately $10^{7} \mathrm{cfu} \mathrm{g}^{-1}$ of product, and the suggested daily intake is approximately $10^{9}$ viable cells (around $100 \mathrm{~g}$ of product per day) (Robinson 1987). Taken together, we conclude that terminating yoghurt after 14 days did not seriously effect to the stability of $B$. longum in faeces.

Fluctuative growth was also observed in L. acidophillus in a similar way to that of $B$. longum. Since $L$. acidophilus is known to use FOS in its fermentation process (Kaplan and Hutkins 2000), population increase by day 14 might be promoted by FOS fermentation in the colon.

When the population of L. acidophilus was examined in the fresh product, a decrease in the population was obtained from day $21\left(9.30 \operatorname{log~cfu~g}^{-1}\right)$ to day $28\left(7.83 \log \mathrm{cfu} \mathrm{g}^{-1}\right)$. The decrease of $L$. acidophillus implies a decrease in bacterial intake to the digestive tract leading to a lower faeces population. However, the population of L acidophillus population significantly increased by day 42 as shown by the population in synbiotic-treated rats of $1.04 \log \mathrm{cfu} \mathrm{g}^{-1}$, which was higher compared to the control (0.92 log cfu g-1) and probiotic-treated rats $\left(0.11 \log \mathrm{cfu} \mathrm{g}^{-1}\right)$.

A decrease in the population of L. acidophilus in rat's faeces was found in synbiotic-treated rats, when the yoghurt intake was terminated for 14 days. The maximum population was $8.34 \mathrm{log}$, which reflects a negative response to the stability of L. acidophillus in the digestive tract. Molin et al. (1993) reported that the normal population of L. acidophilus in faeces is $10^{8} \mathrm{cfu} \mathrm{g}^{-1}$, therefore we conclude that terminating 
the yoghurt intake for 14 days promoted of L. acidophillus population decrease.

L. acidophilus and B. longum population increase in synbiotic yoghurt promotes a decline in E. coli population (Table 3 and 4). Those bacteria, which tend to associate with the membrane of digestive tracts, lead to an increase in the population of native lactobacilli in the digestive tract. Furthermore, this situation inhibits the population of pathogenic bacteria, such as E. coli.

The involvement of lactic acid bacteria in the fermentation process leads to a decreased population of E. coli in the 42-days-treated synbiotic rats. The decreasing population reached $5.90 \log \mathrm{cfu} \mathrm{g}^{-1}$. Lactic acid bacteria have a unique process in their fermentation, in which organic acid is accumulated leading to decrease $\mathrm{pH}$. Lactic acid tends to decrease the $\mathrm{pH}$ value of digestive tract in the range $\mathrm{pH} 4-5$. Since E. coli requires a $\mathrm{pH}$ value in range of 6-7 for optimal growth, the acidic condition dramatically reduce the population of E. coli.

In general, the results on faeces bacterial counts found in our study indicate a great stability of the faeces flora for symbiotic treatments. This has also been found in other studies after different forms of dietary intervention (Bornside 1978; Bartram et al. 1994).

Population of Colon Flora. An increased population of B. longum reflects the effect of FOS content in the yoghurt. The addition of FOS to the yoghurt helps probiotic bacteria through promoting their viability and survivald ability in the digestive tract. This disaccharide composed of fructose and galactose is not digested by humans but is readily fermented by Bifidobacteria as well as by certain bacteria of the resident colonic flora, thus enhancing the selective proliferation and colonization of Bifidobacteria. Fooks et al. (1999) stated that the fermentation of fructans is more favourable to Bifidobacteria than of other carbohydrate sources. Fructan leads to changed microflora composition which is dominated by Bifidobacteria. This fact is known as the bifidogenic effect. Fig 2 shows the effect of treatments to a population of $B$. longum. The population of $B$. longum in synbiotic-treated rats went as high as $11.48 \mathrm{log} \mathrm{cfu} \mathrm{g}^{-1}$ leading to microfloral balance in digestive tract. We conclude that the consumption

Table 3 Bifidobacterium longum population in colon

\begin{tabular}{lc}
\hline Treatment & Population $\left(\log \mathrm{cfu} \mathrm{g}^{-1}\right)$ \\
\hline Control & $9.11 \pm 0.36^{\mathrm{a}}$ \\
Probiotic yoghurt & $8.87 \pm 0.81^{\mathrm{a}}$ \\
Synbiotic yoghurt & $11.48 \pm 0.94^{\mathrm{b}}$ \\
Adaptation & $8.56 \pm 0.63$ \\
Post treatment (no treatment for 14 days) & $8.72 \pm 0.27$ \\
\hline The fonts printed in superscript indicate significant difference between \\
treatments $(\mathrm{p}<0.01)$.
\end{tabular}

Table 4 Lactobacillus acidophillus population in colon

\begin{tabular}{lr}
\hline Treatment & Population $\left(\log \mathrm{cfu} \mathrm{g}^{-1}\right)$ \\
\hline Control & $9.56 \pm 0.31^{\mathrm{a}}$ \\
Probiotic yoghurt & $9.28 \pm 0.66^{\mathrm{a}}$ \\
Synbiotic yoghurt & $11.32 \pm 0.98^{\mathrm{b}}$ \\
Adaptation & $8.72 \pm 0.63$ \\
Post treatment (no treatment for 14 days) & $8.55 \pm 0.23$ \\
\hline
\end{tabular}

The fonts printed in superscript indicate significant difference between treatments $(\mathrm{p}<0.05)$. of PESA goat-milk-based synbiotic yoghurt for 42 days continuously promotes the growth of $B$. longum in the colon.

The low number of $B$. longum, MP to $8.55 \pm 0.23 \log \mathrm{cfu} \mathrm{g}^{-1}$ reflected as adaptation response in -14-days-synbiotic treated rats. It also indicated the disturbances in the stability of B. longum in the colon. A decrease of B. longum intake from synbiotic yoghurt has a vital role for delivering effectiveness. A fail in the population of $B$. longum leads to a reduction of their effect to human health since the population was out of standard population range (Mitsuoka 1978). Alternatively, at low populations of B. longum, pathogenic bacteria can become a dominant group adhering to the digestive tract's membrane. It is suggested that yoghurt consumption must be regular and continuous to supply lactic acid bacteria to the digestive tract. Because the digestion process takes around $12 \mathrm{~h}$ (from mouth to rectum), this means probiotic bacteria must be consumed on daily basis.

The population of $L$. acidophilus in the colon, which increased to $1.32 \log \mathrm{cfu} \mathrm{g}^{-1}$, was beyond the range of the normal population. Molin et al. (1993) reported that the digestive tracts of an adult people was populated by Lactobacilli in a range of numbers, being $10^{2}-10^{4} \mathrm{cfu} \mathrm{g}^{-1}$, $10^{4}-10^{6} \mathrm{cfu} \mathrm{g}^{-1}$ and $10^{8} \mathrm{cfu} \mathrm{g}^{-1}$ in intestine, colon and faeces, respectively. A high population of $L$. acidophilus might be caused by the addition of FOS to synbiotic yoghurt leading it to be used as an energy sources by bacteria to enhance their growth and promote positive effects to host's health. Table 4 shows the average value of the population in all treatments.

The production of bacteriocins by lactobacilli is relatively common, which may contribute to their colonization of a wide range of habitats and their competitive edge over other bacteria (Garriga et al. 1993). The antimicrobial activity of lactic acid bacteria may be due to a number of factors. Among these are decreased $\mathrm{pH}$ levels, competition for substrates and the production of substances with bactericidal or bacteriostatic action, including bacteriocins (Parente and Ricciardi 1999). This was proved by the evidence in our experiments that the population of $E$. coli as one of pathogenic bacteria in the digestive tract was decreased by treating with synbiotic yoghurt (Table 5).

The low number of $L$. acidophilus in the colon was caused by the termination $L$. acidophilus intake from synbiotic yoghurt after 14 days. Furthermore, it initiated inability to complete in adhesion to the digestive tract. As a consequence, pathogenic bacteria would increase, leading to a shift in the microfloral balance in the colon. In some cases, negative effects to human health will occur when such pathogenic bacteria are the dominant group in the digestive tract, i.e. Salmonella, E. coli and Listeria. This leads to an

Table 5 Escherichia coli population in colon

\begin{tabular}{lc}
\hline Treatment & Population $\left(\log \mathrm{cfu} \mathrm{g} \mathrm{g}^{-1}\right)$ \\
\hline Control & $7.48 \pm 0.65^{\mathrm{a}}$ \\
Probiotic yoghurt & $7.16 \pm 1.12^{\mathrm{a}}$ \\
Synbiotic yoghurt & $5.54 \pm 0.12^{\mathrm{b}}$ \\
Adaptation & $8.09 \pm 0.45$ \\
Post treatment (no treatment for 14 days) & $4.58 \pm 0.33$ \\
\hline
\end{tabular}

The fonts printed in superscript indicate significant difference between treatments $(\mathrm{p}<0.05)$. 
increase of carcinogenic compounds, toxins, $\mathrm{NH}_{3}, \mathrm{H}_{2} \mathrm{~S}$, amines and phenolics.

Mitsuoka (1978) stated that $E$. coli can be obtained in the newly born baby and its population tends to increase along with the increase of baby's age. A low population of E. coli in synbiotic yoghurt implies an ability of $L$. acidophillus and $B$. longum to inhibit $E$. coli in the colon. This is caused by the ability of those probiotics to ferment FOS, as a simple sugar monosaccharide, leading to the production of various acidic compounds leading to the inhibition of E. coli. In agreement with our results, Oyetayo et al. (2003) reported that rats that were treated with feed containing L. acidophilus for 3 days had a lower population of Enterobacteria in their faeces.

When synbiotic yoghurt intake was terminated after 14 days, positive effect of probiotic bacteria in decreasing pathogenic bacteria was detected. The results show that by the decreasing this population to $4.58 \pm 0.33 \log \mathrm{cfu} \mathrm{g}^{-1}$ will decrease the E. coli content in the faeces (Fig 3). Therefore, the E. coli population may still decrease, even though yoghurt intake was terminated. It is suggested that this phenomenon is due to the residual effect of antimicrobial activity of L. acidophillus and B. longum. The presence of E. coli, either in faeces or colon, implied that $L$. acidophillus and $B$. longum were able to survive in the digestive tract leading to a decrease in the $E$. coli population.

Sufficient numbers of $B$. longum and $L$. acidophillus cells survived throughout the intestinal track. Synbiotic yoghurt intake significantly increased the population of $B$. longum and $L$. acidophillus, giving a positive effect in inhibiting pathogenic bacteria. It was demonstrated by the decrease E. coli population in the intestine of rats treated with synbiotic yoghurt compared to that of control. Eventhough the population of probiotic bacteria did not severly effect to rats's performance, numerically performance of synbiotic yoghurt-treated rats are better than that of control and probiotic-treated rats.

Negative response was observed in population of $L$. acidophilus and B. longum when synbiotic yoghurt intake was terminated for 14 days. Their populations in colon were similar compare to that of adaptation phase. The results showed that the termination of yoghurt intake led to the decrease of L.acidophillus and B. longum population. In addition, their performace were not as good as the group of rats treated with synbiotic yoghurt 42 days. It was shown by their feed consumption and conversion, which were higher or comparable to that of rats in adaptation phase.

\section{REFERENCES}

Aliaga IL, Alferez MJM, Barrionuevo M, Nestares T, Sampelayo MRS, Campos MS. 2003. Study of nutritive utilization of protein and magnesium in rats with resection of the distal small intestine. Beneficial effect of goat milk. J Dairy Sci 86:2958-2966.

Bartram HP, Scheppach W, Gerlach S, Ruckdeschel G, Kelber E, Kasper H. 1994. Does yoghurt enriched with Bifidobacterium longum affect colonic microbiology and fecal metabolites in healthy subjects? Am J Clin Nutr 59:428-432.

Bornside GH. 1978. Stability of human fecal flora. Am J Clin Nutr 31:5141-5144.
Bouhnik Y, Flourie B, Riottot M, Bisetti N, Gailing MF, Guibert A, Bornet F, Rambaud JC. 1996. Effects of fructooligosaccharides ingestion on fecal Bifidobacteria and selected metabolic indexes of colon carcinogenesis in healthy humans. Nutr Cancer 26:2129.

Bouhnik Y, Vahedi K, Achour L, Attar A, Salfati J, Pochart P, Marteau P, Flourie B, Bornet F, Rambaud JC. 1999. Short-chain fructooligosaccharides administration dose-dependently increases fecal Bifidobacteria in healthy humans. J Nutr 429:113-116.

Collins MD, Gibson GR. 1999. Probiotics, prebiotics, and synbiotics: approaches for modulating the microbial ecology of the gut. Am $J$ Clin Nutr 69:1052S-1057S.

Davidson RH, Duncan SE, Hackney CR, Eigel WN, Boling JW. 2000. Probiotic culture survival and implications in fermented frozen yoghurt characteristics. J Dairy Sci 83:666-673.

Droault S, Corthier G, Ehrlich SD. 1999. Survival, physiology and lysis of lactococcus lactis in the digestive tract. Appl Environ Microbiol 65:4881-4886.

Erickson KL, Neil EH. 2000. Probiotic immunomodulation in health and disease. $J$ Nutr 130:403S-409S.

Fooks LJ, Fuller R, Gibson GR. 1999. Prebiotics, probiotics and human gut microbiology. Probiotica 9:2-7.

Fuller R. 1989. Probiotics in man and animals. J Appl Bacteriol 66:365-378.

Garriga M, Hugas M, Aymerich T, Monfort JM. 1993. Bacteriocinogenic activity of lactobacilli from fermented sausages. J Appl Bacteriol 75:142-148.

Gibson GR, Beatty ER, Wang X, Cummings JH. 1995. Selective stimulation of Bifidobacteria in the human colon by oligofructose and inulin. Gastroenterology 108:975-982.

Gibson GR, Roberfroid MB. 1995. Dietary modulation of the human colonic microflora: introducing the concept of prebiotics. $J$ Nutr 125:1401-1412.

Gibson GR, Wang X. 1994. Bifidogenic properties of different types of fructo-oligosaccharides. Food Microbiol 11:491-498.

Heller KJ. 2001. Probiotic bacteria in fermented foods: product characteristics and starter organisms. Am J Clin Nutr 73:374S379 S.

Hopkins MJ, Cummings JH, McFarlane GT. 1998. Inter-species differences in maximum specific growth rates and cell yields of Bifidobacteria cultured on oligosaccharides and other simple carbohydrate sources. J Appl Microbiol 85:381-386.

Jandal JM. 1996. Comparative aspects of goat and sheep milk. Small Rumin Res 22:177-185.

Jin L J, Ho YW, Abdullah N, Kodo H, Jalaludin S. 1997. Studies on the intestinal microflora of chickens under tropical conditions. AsianAust J Anim Sci 10:495-504.

Kaplan H, Hutkins RW. 2000. Fermentation of fructooligosaccharides by lactic acid bacteria and Bifidobacteria. Appl Environ Microbiol 66:2682-2684.

Kolida S, Tuohy K, Gibson GR. 2002. Prebiotic effects of inulin and oligofructose. Br J Nutr 87:193-197.

McDonough FE, Hitchins AD, Wong NP. 2006. Effects of yoghurt and freeze-dried yoghurt on growth stimulation of rats. J Food Sci 47:1463-1465.

McKellar RC, Modler HW. 1989. Metabolism of fructooligosaccharides by Bifidobacterium spp. Appl Microbiol Biotechnol 31:537-541.

Molin G, Jeppsson B, Johansson ML, Ahrne S, Naboek S, Stahl M, Bergmark S. 1993. Numerical taxonomy of Lactobacillus spp. Associated with healty and diseased mucosa of human instestines. J Appl Bacteriol 74:314-323.

Oyetayo VO, Adetuyi FC, Akinyosoye FA. 2003. Safety and protective effect of Lactobacillus acidophilus and Lactobacillus casei used as probiotic agent in vivo. Afr J Biotechnol 2:448-452.

Palframan RJ, Gibson GR, Rastall RA. 2003. Carbohydrate preferences of Bifidobacterium species isolated from the human gut. Curr Issues Intest Microbiol 4:71-75.

Parente E, Ricciardi A. 1999. Production, recovery and purifications of bacteriocins from lactic acid bacteria. Appl Microbiol Biotechnol 52:628-638.

Perrin S, Warchol M, Grill JP, Schneider F. 2001. Fermentation of fructooligosaccharides and their components by Bifidobacterium infantis ATCC 15697 on batch culture in semi-synthetic medium. J Appl Microbiol 90:859-865. 
Poschart P, Marteau P, Bouhnik Y, Godenel I, Bourlioux P, Rambaud IC. 1992. Survival of bifidobactenia ingested via fermented milk during their passage through the human small intestine: an in vivo study using intestinal perfusion. Am J Clin Nutr 55:78-80.

Razafindrakoto O, Ravelomanana N, Rasolofo A, Rakotoarimanana RD, Gourgue P, Coquin P, Briend A, Desjeux JF. 1994. Goat's milk as a substitute for cow's milk in undernourished children: a randomized double-blind clinical trial. J Dairy Sci 94:65-69.

Robinson RK. 1987. Survival of Lactobacillus acidophilus in fermented products. S Afr Tydskr Suiwelk 19:25-27.

Salminen S, Bouley C, Boutron-Ruault MC, Cummings JH, Franck A, Gibson GR, Isolauri E, Moreau MC, Roberfroid M, Rowland I.
1998. Functional food science and gastrointestinal physiology and function. Br J Nutr 80:S147-S171.

Shene C, Mardones M, Zamora P, Bravo S. 2005. Kinetics of Bifidobacterium longum ATCC 15707 fermentations: effect of the dilution rate and carbon source. Appl Microbiol Biotechnol 67:623-630.

Wang X, Gibson GR. 1993. Effects of the in vitro fermentation of oligofructose and inulin by bacteria growing in the human large intestine. J Appl Bacteriol 75:373-380.

Yamazaki H, Dilawri N. 1990. Measurement of growth of Bifidobacteria on inulinofructosaccharides. Lett Appl Microbiol 10:229-232. 